the $\mathrm{Y}$ chromosome, or at least the terminal part of its long arm, might alter its reaction to specific fluorochromes.

All in all we favour the use of Q.M., which in our experience has been more consistent than Q., on peripheral blood for routine laboratory application.

Quinacrine mustard was kindly donated by the Cancer Chemotherapy National Service Center, National Institutes of Health, Bethesda, U.S.A. Mr. L. Kelberman advised on and helped with the photography. The work was supported by the Spastics Society.

\section{References}

Barlow, P., and Vosa, C. G. (1970). Nature, 226, 961.

Caspersson, T., et al. (1968). Experimental Cell Research, 49, 219.

Caspersson, T., Zech, L., and Johansson, C. (1970a). Experimental Cell Research, 60, 315.

Caspersson, T., Zech, L., Johansson, C., and Modest, E. J. (1970b). Chromosoma, 30, 215

George, K. P. (1970a). Nature, 226, 80.

George, K. P. (1970b). Stain Technology. In press.

Loveless, A. (1970). Nature, 227, 101.

Pearson, P. L., and Bobrow, M. (1970). Nature, 226, 959.

Pearson, P. L., Bobrow, M., and Vosa, C. G. (1970). Nature, 226, 78.

\title{
Headache and Blood Pressure in the Community
}

\author{
W. E. WATERS
}

British Medical fournal, 1971, 1, 142-143

\section{Summary}

Following a survey of headaches, in which questionnaires were sent to a random sample of the general population, groups of individuals with headache, unilateral headache, or migraine, and a fourth group who had not had a headache in the previous year were examined. Measurements of arterial blood pressure on 414 individuals gave no evidence of any differences between these groups for either systolic or diastolic pressure. The number of individuals that could be regarded as hypertensive in this community-based study was small, but it is concluded that most individuals with headache, and with migraine, have blood pressures similar to those who do not have headaches.

\section{Introduction}

There are widely conflicting opinions about the association of headache and migraine with arterial blood pressure. The view that headache is a common symptom in hypertension (Wolff, 1963; Pickering, 1968) apparently contradicts the statement that "it is generally agreed that moderate hypertension alone does not cause headache" (Selby and Lance, 1960). A recent survey showed no significant differences in the prevalence of headaches in hypertensive patients with diastolic pressures of up to $130 \mathrm{~mm} \mathrm{Hg}$ when compared with normotensive controls selected from other clinics at the same hospital (Al Badran et al., 1970).

A study in general practice concluded that patients with migraine have significantly higher systolic and diastolic pressures than those without migraine and that, age for age, this difference averaged about $10 \mathrm{~mm} \mathrm{Hg}$ (Walker, 1959). Blood pressure levels may, however, fall during migraine attacks (Pfeiffer et al., 1943) and, contrary to the general view, it has even been stated that most patients with migraine tend to have low blood pressures (MacNeal, 1949).

Only about half of all migraine sufferers attend a doctor for their headaches (Waters and O'Connor, 1970) and the proportion of headache sufferers seeking attention is even lower. Therefore only representative community samples can give reliable evidence of any association between headaches and blood pressure.

\footnotetext{
Medical Research Council's Epidemiology Unit (South Wales), Cardiff, CF2 3AS

W. E. WATERS, M.B., D.I.H., Member of Staff (Present appointment : Senior Lecturer in Ćlinical Epidemiology and Community Medicine, University of Southampton)
}

\section{Methods}

Following a survey in which a random sample of 1,838 adults in the Pontypridd area of Glamorgan were sent questionnaires on headache, random samples of individuals with migraine, unilateral headache, headache, and a fourth group without headache in the year immediately preceding the survey were examined. Details of these samples, the response rates, and some ophthalmological data have been published (Waters, 1970). The correlation between the migraine group, identified by the questionnaire, and a neurologist's clinical diagnosis has been measured (Waters and O'Connor, 1970). All arterial blood pressures were measured with a standard mercury manometer by one observer, who is a State-registered nurse, after the individuals had been sitting for at least five minutes. Diastolic pressures were taken at the point when muffling of the sounds occurred. All readings were recorded to the nearest $5 \mathrm{~mm} \mathrm{Hg}$. During the survey the observer was unaware of the headache histories of the individuals examined.

\section{Results}

The mean systolic and diastolic blood pressures, and the standard deviations about these means, are given in Table I. Both systolic and diastolic pressures increased significantly with increasing age. For men the age structure of the four "headache groups" did not differ significantly, and the distributions of systolic and diastolic blood pressure are given in the Chart. Analyses of variance showed no significant difference between the groups for either systolic pressure $(0.1<\mathrm{P}<0.2)$ or diastolic pressure $(0.2<\mathrm{P}<0.3)$.

In women, because of the significantly different age structure of the four headache groups, analyses of variance were done for each of the three age groups 21-34, 35-54, and 55-74 years. In none of these analyses was the variance between groups significantly greater than the variance within groups (at $\mathrm{P}<0.05$ ) for either systolic or diastolic pressure. The number of individuals with systolic pressures of $195 \mathrm{~mm} \mathrm{Hg}$ or greater and with diastolic pressures of $115 \mathrm{~mm} \mathrm{Hg}$ or greater is shown, by headache group, in Table II. These numbers are too small for detailed analysis but certainly do not suggest any predominance in those with headache.

\section{Discussion}

The view, formerly generally held, that headache is a common symptom of hypertension has been challenged, especially 
TABLE I-Mean Blood Pressure, and Standard Deviation, by Headache Group

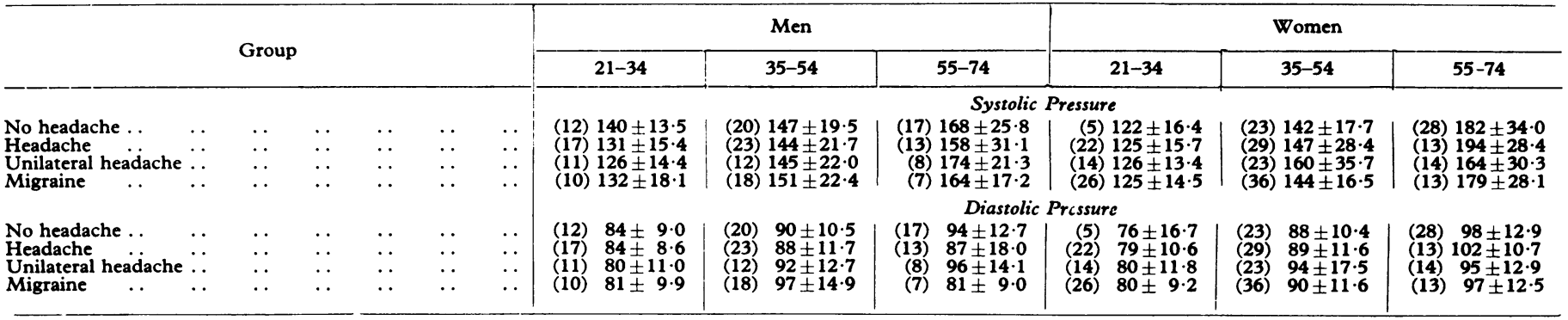

Figures in parentheses show number examined.

TABLE II-Number of Subjects, by Headache Group, with High Systolic and with High Diastolic Blood Pressures

\begin{tabular}{|c|c|c|c|c|c|c|c|}
\hline \multirow{2}{*}{\multicolumn{2}{|c|}{ Group }} & \multicolumn{3}{|c|}{ Men } & \multicolumn{3}{|c|}{ Women } \\
\hline & & $\begin{array}{c}\text { No. } \\
\text { examined }\end{array}$ & $\stackrel{\text { Systolic }}{>195}$ & $\underset{\substack{\text { Diastolic } \\
>115}}{ }$ & $\begin{array}{c}\text { No. } \\
\text { examined }\end{array}$ & $\begin{array}{c}\text { Systolic } \\
>195\end{array}$ & $\begin{array}{c}\text { Diastolic } \\
>115\end{array}$ \\
\hline $\begin{array}{l}\text { No headache } . . \\
\text { Headache } \\
\text { Unilateral headache } \\
\text { Migraine .. }\end{array}$ & $:$ & $\begin{array}{l}49 \\
53 \\
31 \\
35\end{array}$ & $\begin{array}{l}4 \\
2 \\
2 \\
0\end{array}$ & $\begin{array}{l}0 \\
1 \\
1 \\
1\end{array}$ & $\begin{array}{l}56 \\
64 \\
51 \\
75\end{array}$ & $\begin{array}{r}10 \\
8 \\
6 \\
4\end{array}$ & $\begin{array}{l}3 \\
2 \\
3 \\
2\end{array}$ \\
\hline Total $\ldots$ & & 168 & 8 & 3 & 246 & 28 & 10 \\
\hline
\end{tabular}

during the past 20 years (Platt, 1950; Stewart, 1953). As long ago as 1931 Ayman and Pratt gave clinical evidence that the early symptoms of essential hypertension, of which headache was the commonest, were of psychic origin. It has been suggested that many patients experience headache only after they are told that they have high blood pressure (Platt, 1950; Stewart, 1953; Sainsbury, 1964). This may be the explanation for Walker's (1959) finding that in 300 consecutive patients over the age of 40 years the prevalence of migraine rose as the blood pressure increased. Alternatively, this apparently direct relationship between migraine and high blood pressure may have resulted from the general practitioner's knowledge of his patients, as bias would have been difficult to eliminate and there is no record of the study being "blind." Robinson

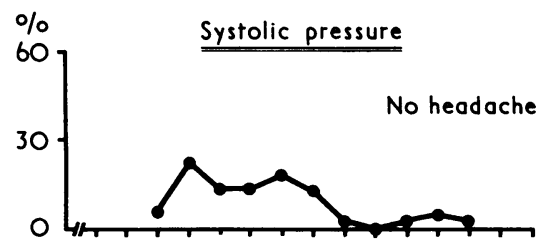

Diastolic pressure
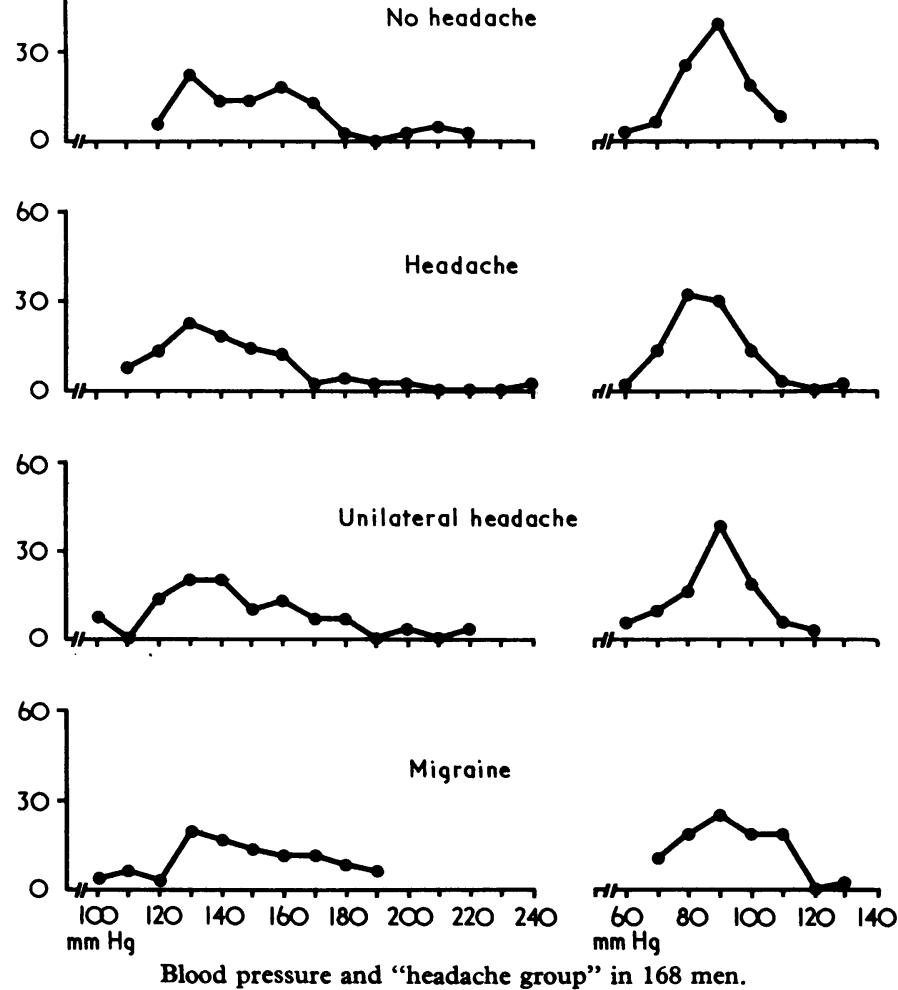

(1969) found that symptoms were not related to hypertension in individuals visiting their doctors but that certain symptoms, and particularly headache, made general practitioners more likely to measure a patient's blood pressure. This is likely to lead to an underestimate of the number of patients with high blood pressures and no headaches, so that any analyses based on general practitioners' records, such as the main part of Walker's (1959) study, may be biased.

The present study, based on representative samples of individuals with migraine, unilateral headache, and headache, and individuals without headache in the year immediately preceding the survey, gives no evidence of any difference in the distribution of either systolic or diastolic blood pressure in these four groups. The design of this research was such that the possibilities of bias in the identification of individuals with migraine and headache, or during the measurement of blood pressure, were reduced to a minimum. The number of individuals seen who would normally be regarded as hypertensive was fairly small; 36 individuals had systolic pressures of $195 \mathrm{~mm} \mathrm{Hg}$ or above and only 13 individuals had diastolic pressures of $115 \mathrm{~mm} \mathrm{Hg}$ or above. It has been suggested that, relatively rarely, a headache which resembles migraine can result directly from hypertension (Stewart, 1953). In hospital clinic patients Al Badran et al. (1970) found headache occurred significantly more often in those with diastolic pressures of $130 \mathrm{~mm} \mathrm{Hg}$ or above. Stewart's (1953) data suggested that severely hypertensive patients are more likely to know of their disease and thus the increased prevalence of headache may be, at least in part, a result of increased awareness. Whether or not there is a small group of hypertensives in whom headache is directly related to the high blood pressure, this community survey on the prevalence of headache does not suggest that raised blood pressure is an important factor.

I am grateful to Professor A. L. Cochrane, Director of the Epidemiology Unit (South Wales), for encouragement and advice. I thank Mr. E. Welsby for measuring the blood pressure and Miss Margaret Abernethy for help with the statistical calculations. This research was aided by a grant from the Migraine Trust.

\section{References}

Al Badran, R. H., Weir, R. J., and McGuiness, J. B. (1970). Scottish Medical Fournal, 15, 48.

Ayman, D., and Pratt, J. H. (1931). Archives of Internal Medicine, 47, 675. MacNeal, P. S. (1949). Medical Clinics of North America, 33, 1581.

Pfeiffer, C., Dreisbach, R. H., Roby, C. C., and Glass, H. G. (1943). Fournal of Laboratory and Clinical Medicine, 28, 1219.

Pickering, G. (1968). High Blood Pressure. London, Churchill.

Pickering, G. (1968). High Blood Pressure. London,
Platt, R. (1950). British Medical .7ournal, 1, 951.

Platt, R. (1950). British Medical fournal, 1, 951.

Robinson, J. O. (1969). Fournal of Psychosomatic Research, 13, 157.
Sainsbury, P. (1964). Fournal of Psychosomatic Research, 8, 235.

Selby, G., and Lance, J. W. (1960). Fournal of Neurology, Neurosurgery and Psychiatry, 23, 23.

Stewart, I. McD. G. (1953). Lancet, 1, 1261.

Walker, C. H. (1959). British Medical fournal, 2, 1430

Waters, W. E. (1970). Lancet, 2, 1.

Waters, W. E., and O'Connor, P. J. (1970). In Background to Migraine: Third Migraine Symposium, ed. A. L. Cochrane, p. 1. London, Heine-

mann.
Wolff, H. G. (1963). Headache and Other Head Pain. New York, Oxford University Press. 